\section{Ethical Lingua}

Journal of Language Teaching and Literature

ISSN 2355-3448 (Print) ISSN 2540-9190 (Online)

Volume 4, Number 1, February 2017 pp. $68-75$.

\title{
Modulation in Translation Process
}

\author{
Kartini Rahmatillah \\ kartinirahmatillah@ymail.com \\ Sekolah Tinggi IImu Ekonomi (STIE) Madani Balikpapan, Indonesia \\ Submitted : 24 January 2017, Accepted: 2 February 2017 \\ URL : : http://journal.uncp.ac.id/index.php/ethicallingua/article/view/334
}

\begin{abstract}
Many aspects have to be observed by translators in order to make a good and equivalent translation. One of these is meaning, because it is the main goal translators must reach in their translation activity. The object of this preliminary research was on the modulation or the shifting of meaning in the process of translation. This preliminary research was qualitative naturalistic research. It used the samples of translation, both from Indonesian to English and from English to Indonesian. The words that needed modulation were classified, the patterns of the words were analyzed and finally conclusion was drawn. The source text were about social and religious affairs, i.e. the training module for companionship for victims of violence against women (VAW) and Section III Chapter 14 and Glossary of Teaching and Researching Translation (Hatim, 2001). The aims of this preliminary research were to find out (1) what kinds of pattern that are said to be modulated, and (2) whether each pattern, either from TSu or TSa carries the same or different meaning. The result from this preliminary research showed that each pattern, even though different between TSu and TSa carries the same meaning and the patterns that are modulated were the changing of passive in TSu to active in TSa and both passive in TSu and TSa.
\end{abstract}

Keywords: Shifting in Meaning, Modulation, Translation

\section{Introduction}

The translation is now accepted as a profession that requires a certain skill so that the translation is no longer considered a mere skill. Many things that should not be ignored in translation so that someone with specific language skills are not necessarily able to translate a text well, even college students or anyone who can speak English, for example, does not necessarily translate well. Many 
aspects must be considered and comprehended at the same time by the translator. One of the very important aspects is the meaning because these aspects are the main objectives of translators. Raw material of translators is words that must be transferred into words in target language words and must have the same meaning from the source words. Why does meaning is so important in the translation? First, the components of meaning are always packed in the points of lexical (words) but the way translators transfer the words maybe different between the sources to the target language. Second, the components of the same meaning may appear in different words. Third, a certain word could be used to represent multiple meanings. Fourth, a meaning can be expressed with many different kinds of words (Larson, 1984: 6 in Suryawinata, 2003: 91).

The meaning of a word is not only influenced by its position in the sentence but also a field of science that uses the word. Not infrequently, the meaning of a word is determined by its use and cultural situation of the speakers of a language (Nababan, 1999: 47). In the practice of translation, the translator's attention is focused not only on the transfer of the meaning of a word, but extends to the transfer of the message or the message that will be conveyed to the reader (Nababan, 1999: 48). Being the importance of meaning in translation, this paper will mainly discuss about a shift or modulation in meaning that occur in the process of translation, both in translation from Indonesian to English and translations from English to Indonesian.

In this research, the issues that are going to be discussed, especially regarding the patterns of what causes the shift in meaning (modulation) in the process of translation, both in the translation from English to Indonesian and the translation from Indonesian to English. In this research it will be known how the patterns cause a shift in meaning or modulation. It will also be known whether each pattern of TSU and TSA have different meanings, or remain the same despite having different patterns.

\section{Methodology}

This research is a qualitative naturalistic research because the data obtained is a verbal data. The samples were studied in the form of material translated from Indonesian to English and from English into Indonesian. The first sample in the form of a training module to provide assistance to victims of violence against women of Puan Amal Hayati. While the second sample studied was obtained from material taken from a translation of Basil Hatim's book entitled "Teaching and Researching Translation" (2001). Both of these samples serve as the study sample as it includes many terms that are difficult to find the equivalent terms. Researcher collected samples of these translations, classify words that undergo modulation, formulate patterns of words, both from the TSU and the TSA, and then analyze and summarize. 


\section{Result}

\section{Meaning Shifting}

Meaning shifting usually happens sometimes due to a shift or change in a shape from source language (BSu) to target language (BSa). This occurs because of changes in perspective, viewpoint, or other meaningful terms. A shift in meaning is known as modulation. Vinay \& Darbelnet (in Newmark, 1988: 88) states that the term modulation refers to "a variation through a change of viewpoint, of perspective and very often of a category of thought." The shift of meaning or modulation is divided into two (2) kinds, they are compulsory modulation and free modulation. Compulsory modulation must be done by translators when a word, phrase or structure being translated has no equivalent terms in the BSA so it needs to be modulated by creating such new terms. Modulation of this type include:

a. Active structures in the Source Text (TSu) become passive in the Target Text (TSa) and vice versa.

In the sample below there is a common modulation type that shows changes in the structure of the passive to active in the TSA TSU.

\section{Example 1:}

TSu: $\quad$ Dikabarkan suaminya sekarang telah menikah dengan sesama TKI di Arab Saudi (Training Modul Puan Amal Hayati: 82)

TSa: $\quad$ People say that her husband has got married again with one of his fellow laborers in Saudi Arabia

$\begin{array}{ll}\text { TSu: } & \frac{\text { Dikabarkan }}{\text { passive with prefix /di-/ }} \\ \text { TSa: } & \frac{\text { People say that }}{\text { active with prefix } / \mathrm{me}-/}\end{array}$

At the TSU above, the sentence starts with a passive verb "rumored" but later it changed to "people say that ..." in TSA. Here the verb prefix / di- / turned into prefix / me- / so that the structure directly will change from the previous structure of passive to active. Both these sentences if it is seen from the pattern, does not cause significant changes in the meaning of the second sentence because in essence translator wants to tell the reader that "the perpetrators husband had married again". These prefixes change also signifies that the sentence in TSU more emphasize on the process activities while in the TSA the sentence emphasize the subject who did the activity. In the end for the overall message or the meaning of the second sentence in both the TSU and the TSA has not changed, it means that the meaning of the second sentence remains the same despite having different pattern and structure. 


\section{Example 2:}

BSu: Sejak kecil ia biasa diperintah oleh ayahnya... (Training Modul Puan Amal Hayati : 83)

BSa: $\quad$ she used to do everything her father said since childhood

In the example above, it also happens the same as in Example 1 where the change from passive structure into active structure happened. Changes in the structure are characterized by the use of different prefixes between them, namely the prefix / di- / in TSU and prefix / me-/ in TSA.

In the translation from Indonesian to English, there are found many of such a structure, namely the structure of passive in Indonesian. TSU mainly used the passive voice patterns which are marked with the prefix / di- / while TSa used the active sentence patterns with the use of the prefix / me- /. This is because this kind of sentence patterns in English is not common, so that it must be converted into active pattern in TSA. Therefore, the structure of passive in the Indonesian language is translated into active structures in English. This is where the modulation occurs.

b. The subject structure that is split in Indonesian needs modulation by combining it to Indonesian.

\section{Example}

TSu: pentingnya kepercayaan dalam pendampingan
TSa: the importance of trust in companionship to victims of VAW
TSu: $\quad$ pentingnya kepercayaan dalam pendampingan.
TSa: Phrase with pattern of D ('pentingnya') M ('kepercayaan')

In the example above, the changing pattern of shapes phrase (TSU) to form clause (TSA) happened. In TSA the clause is more explaining what is meant in TSU but does not change the overall meaning. Between TSU and TSA after a change in the pattern (shape), the meaning does not change significantly or remain the same. The meaning of the second sentence remains the same even though the pattern was different.

Compulsory modulation also occurs in the translation of the word whose meaning can be revealed the equivalence only half in the TSA, which is from specific meaning to general meaning (Machalli, 2000: 70). Example: in TSU (Indonesian) word "hijab" is translated into TSA (English) to "veil". Here the word implies the hijab headscarf used by Muslim women to cover the head and the rule regarding the use is quite strict. While the word "veil" refers to something to cover the head only. So that the specific terms of 'hijab' was changed to 'veil' which is a more general term. 


\section{Free Modulation}

Free Modulation is a free translation procedure that is done for the reason of nonlinguistic, for example, to clarify the meaning, to create equivalence in target language (BSa), looking for matching that feels natural in BSA, and so on. Here are some examples of free modulation which are also present in the samples being analyzed:

a. TSA stated explicitly what is implied in the TSU. But it can also happen the other way around where translators reveal the implicit terms in TSa become explicit in TSU.

\section{Example}

$\begin{array}{ll}\text { TSu } & : \text { word "pengajian" } \\ \text { TSa } & : \text { translated into "a kind of religious activity" } \\ \text { TSU } & : \text { pengajian - word } \\ \text { TSa } & : \underline{\text { a kind of religious activity - phrase }}\end{array}$

The word 'pengajian' changed into more common phrase because translator did not found an equivalent match in the target language. Meaning contained between the two terms is also changed indirectly from specific meaning to more general meaning. Having no equivalent terms for the change is because of cultural factors of the target language that does not know the intended word like in the source language, so that the word is translated into a more common phrase. Translation became implied because it does not accurately depict what it meant in the word "pengajian".

b. Prepositional phrase of cause and effect in TSu become a cause-effect clause in TSa.

\section{Example}

TSu: $\quad$ Sejak itu Ima sering dituduh mencuri oleh para tetangganya jika ada kehilangan di sekitar rumahnya

TSa: $\quad$ Since that time, Ima has often been accused of stealing something if her neighbor lost their things

\section{Overt and Covert in Translation}

Overt translation is done if the source text is mainly devoted to the culture of the source and therefore can only be linked to the original text of social culture (Hatim, 2001: 94). Translation by using the strategy of "overt" is performed by translating the text of BSU to BSA without shifts or changes in the BSA. Source language text actually translated purely without making changes. 


\section{Example}

TSu : Abu Hurairah mendengar Rasulullah SAW bersabda:

Law anna al-mar'ata min al-maali mitslu Sulaiman ibnu Daud a'laihima alsalaam wa

likullihi zaujihaa tsumma gaalat lahu : aina maalii? Illa ahbathallakhu a'laihimaa

arbaii'na sanah

Meaning : Andaikata seorang perempuan mempunyai harta kekayaan seperti kerajaan Nabi

Sulaiman bin Daud dan suaminya memakan harta itu, lalu ia bertanya kepada suaminya

"dimana hartaku?" Allah pasti melebur 40 tahun amal perempuan itu.

TSa

: Even if a woman had a wealth like prophet Sulaiman, son of Daud AS, and her husband spent that wealth, then she asked him "where is my wealth?", God would certainly destroy her 40-year's good deeds.

"Covert" translation is to translate the source language text into the target language text by searching the equivalent terms in the target language, so that the reader with the capability of understanding the target language does not feel the text as translated captions. Example of translation with the strategy of "covert" is shown in the text taken from the example translation glossary in the book of Hatim, 2001: 230.

\section{Example of Covert Translation}

BSu: $\quad$ Free Translation

A type of translation in which more attention is paid to producing a TT which reads more naturally than one which adheres closely to ST wording (Hatim, 2001: 230)

BSa: Jenis penerjemahan yang lebih menekankan pada bagaimana menghasilkan terjemahan yang dapat dibaca lebih alami dibanding terjemahan yang terikat dalam teks sumber.

Another example of 'covert' translation (TSu from the 'overt'translation):

TSa: If a woman were as wealthy as prophet Solomon, the son of David, and her husband spends that wealth, then she asks him "where is my wealth?" God will certainly destroy the 40year good deeds of hers

\section{Discussion}

From the result of the Indonesian translation into English above, there seems an adjustment in terms of grammar to gain a relevant and commonly used equivalence in the target language. Despite these adjustments, there are no shift meaning happen significantly because the meaning from the TSu and the TSa above basically can still be understood.

The translator who did the covert translation, made few changes to match the source language text with a target language text. This is done due to the translation in the target language can be understood as to understand the text in the source language. 
A shift in meaning that occurs in the process of translation is actually an event that is natural and common. This is because in creating a good translation in terms of equivalent translation, sometimes necessary changes happens to adjust to the meaning contained in the source text. It is where the shift of meaning happen. Shifting meanings also varies, sometimes found a shift in meaning that occurs in certain texts where other meaning shift does not occur.

Researcher concluded that in any form of language, ranging from phonemes to words, it has meaning respectively. As we know that in any language there are two important aspects, namely the shape and meaning. Words, phrases, clauses, sentences, paragraphs, and so included in this aspect of the shape or surface structure while the meaning is included in the structure or the semantic structure. Behind every surface structure there lies the depth structure (meaning) (Simatupang, 1999: 16).

In the examples of translations given above, we can conclude that the translation of the two samples studied, obtained various kinds of patterns are different from one another, between TSU and TSA. Besides from patterns that have different meanings, the shape shifting that occurs is in the form of a shift in meaning which involves changing the structure from passive to active. This is because the structure prevailing in the Indonesian learn more about the structure of passive rather than active. Another shift in the meaning that is in the form of changes in the form of words into phrases and phrases into clause.

In the translation process, it is possible to make shift in meaning. The form of shift in meaning or modulation that occurs in the translation may vary depend on the material or the translated text. Often the shift in meaning between one translations to another translation is different. This is because of the difficulties faced by each translator is not the same either.

\section{Conclusion}

From the above discussion, it can be concluded that the patterns that lead to a shift in meaning are patterns at TSU which in form of prefix / di- / but then turned into prefix / me- / in TSA. Due to changes in this pattern then there is also a shift in meaning from passive structure changed into an active structure.

A shift in meaning or modulation is an event that is often encountered in the process of translators. A shift in meaning occurs usually because the translator had to make adjustments to generate text in the target language that can be read more naturally as the source text. A shift in meaning often arises because the translator should seek appropriate equivalent to the source text that is being translated. The process of matching the most appropriate search that makes the translator must make changes, changes in shape in the form of words, phrases, or clauses, as well as other changes.

Professional translators certainly should pay attention in terms of meaning rather than form, because of this factor is the most important thing in the process 
of translation. Translators are allowed to change the shape but it does not mean that they can change the original meaning because the translator only act as a messenger of the author of the source text for the reader to understand the intention of the target language and the message from the author. What is being submitted is the message of the not the message of the translator.

\section{References}

Hatim, B. (2001). Teaching and Researching Translation. England: Pearson Education Limited.

Machali, R. (2000). Pedoman bagi Penerjemah. Jakarta: PT Grasindo.

Nababan, R. (1999). Teori Menerjemah Bahasa Inggris. Yogyakarta: Pustaka Pelajar.

Newmark, P. (1988). A Textbook of Translation. New York: Prentice Hall International.

Simatupang, M.D.S. (1999). Pengantar Teori Terjemahan. Direktorat Jenderal

Pendidikan Tinggi Departemen Pendidikan Nasional.

Suryawinata \& Hariyanto. (2003). Translation Bahasan Teori \& Penuntun Praktis Menerjemahkan. Yogyakarta: Penerbit Kanisius. 